\title{
CORRIGENDUM
}

\section{Foreign live-in domestic workers as caretakers of older Kuwaiti men and women: socio-demographic and health correlates - CORRIGENDUM}

\author{
NASRA SHAH*, HANAN BADR* and MAKHDOOM SHAH $†$
}

doi:10.1017/So144686X11000778, Published by Cambridge University Press 24 August 2011.

In the published article Shah et al. (2012) on page 1008 of this issue, the name and affiliation of one of the co-authors is missing.

The intended authors list should have read; NASRA SHAH, HANAN BADR, KATHRYN M. YOUNT and MAKHDOOM SHAH

Kathryn M. Yount is Affiliated to Emory University, USA.

\section{REFERENCE}

Shah, N., Badra, H. and Shah, M. 201 2. Foreign live-in domestic workers as caretakers of older Kuwaiti men and women: socio-demographic and health correlates. Ageing E Society, 32, 6, 1008-1029. 